\title{
PROTEINS OF TRANSCRIPTIONALLY ACTIVE AND INACTIVE CHROMATIN FROM FRIEND ERYTHROLEUKEMIA CELLS
}

\author{
A. F. $\mathrm{LAU}^{1}$ and R. W. RUDDON ${ }^{2}$ \\ Department of Pharmacology, The University of Michigan Medical School, \\ Ann Arbor, MI 48109, USA
}

\begin{abstract}
SUMMARY
Transcriptionally active and inactive chromatin fractions were prepared from control and dimethyl sulfoxide (DMSO)-treated murine erythroleukemia cells by the DNase II technique of Gottesfeld et al. (Proc natl acad sci US 71 (1974) 2193). The active and inactive chromatin fractions from control and DMSO-treated cells had essentially the same total histone content, but the active chromatin fractions from both control and treated cells contained significantly less $\mathrm{H} 1$ histone. The amount of non-histone protein was similar in the corresponding chromatin fractions of control and treated cells. For both treated and control cell chromatin, however, the content of non-histone protein was consistently lower in the inactive fraction, $P_{2}$, than in the active fraction, $S_{2}$. No significant differences were observed between the polyacrylamide gel banding patterns, as determined by Coomassie blue staining, of histone or non-histone chromatin proteins of the corresponding fractions from treated and control cells. However, dual radioisotope labeling studies indicated an increased incorporation of radioactive amino acids into a $50000 \mathrm{D}$ polypeptide of unfractionated chromatin and a $23000 \mathrm{D}$ polypeptide of active chromatin $\left(\mathrm{S}_{2}\right)$ from DMSO-treated cells.
\end{abstract}

Friend murine erythroleukemia cells, which resemble pro-erythroblasts, can be stimulated to differentiate by the addition of dimethyl sulfoxide (DMSO) to their growth medium [1-3]. Differentiation includes: $(i)$ the production of hemoglobin [1, 2]; (ii) morphological changes, such as a decrease in the nuclear: cytoplasmic ratio and in the overall size of the cells [1]; (iii) production of erythrocyte membrane-specific antigens [4]; (iv) increase in the activities of $\delta$-aminolevulinic acid synthetase and carbonic an-

\footnotetext{
${ }^{1}$ Present address: Department of Microbiology, University of Minnesota, Minneapolis, MI 55455, USA.

2 Present address: Biological Markers Laboratory, Frederick Cancer Research Center, Frederick, MD 21701 , USA. To whom reprint requests should be addressed.
}

hydrase [5-7]; and ( $v$ ) an accumulation of globin mRNA which occurs prior to the appearance of hemoglobin [8-10]. It is presently thought that the latter primarily represents a transcriptional event $[8,9]$. Since chromatin-associated proteins are thought to play a regulatory role in gene transcription, one might expect changes to occur in the content or turnover of chromatin-associated proteins in DMSO-treated erythroleukemia cells.

The ability to detect alterations in regulatory elements involved in gene activation may be enhanced by the preparation of actively transcribed chromatin fractions. Since the first attempt by Frenster et al. [11], several procedures have been devised to accomplish this goal. These schemes rely 
on the fragmentation of chromatin into small pieces by physical shearing or nuclease digestion followed by column chromatography or differential centrifugation to separate the chromatin fractions (recently reviewed in ref. [12]). Transcriptionally active chromatin has been found to $(i)$ contain higher specific activity nuclear RNA after pulse labeling $[11,13,14]$; (ii) have a higher in vitro template activity (measured by addition of $E$. coli RNA polymerase) [13-16]; (iii) be enriched in NHCP and deficient in histones, particularly Hl $[16,17]$. The DNase II digestion technique of Gottesfeld et al. [16] produces active chromatin with several unique characteristics. The putative active fraction, besides possessing most of the previously mentioned features of active chromatin, consists of a distinct tissuespecific subset of non-repetitive DNA sequences compared to unfractionated chromatin [16, 18]. Furthermore, Gottesfeld et al. [19] have recently shown that both transcriptionally active and inactive chromatin contain "subunits" of nucleoprotein. The nuclease resistant structures of inactive chromatin are DNA-histone complexes resembling $\nu$ bodies; however, those from active chromatin are complexes of DNA, RNA, histone and non-histone protein. This method also allows one to obtain relatively large pieces of DNA (average double-stranded chain length of approx. 700 nucleotide pairs) from chromatin under ionic conditions which permit minimal protein exchange $[16,20]$. These results suggest that there is some difference in the structural organization of active and inactive chromatin. The rationale for the studies presented in this manuscript is based on the assumption that a difference in chromatin structure would be reflected in chromatin proteins. With the use of the DNase II method, we find that there are some detect- able differences in the incorporation of radiolabeled amino acids into histones and specific non-histone proteins in DMSOtreated erythroleukemia cells.

\section{MATERIALS AND METHODS}

\section{Growth and stimulation of cells}

The $\mathrm{T} 3-\mathrm{Cl}-2$ clone of Friend murine erythroleukemia cells, established by Ikawa \& Sugano [3], was obtained from the NIH through the courtesy of Dr Philip Leder. Cells were grown for $120 \mathrm{~h}$ in RPMI-1640 (Gibco) supplemented with $10 \%$ fetal calf serum. The culture medium to be added to the "treated" group was adjusted to $1.2 \%$ DMSO ( $\mathrm{v} / \mathrm{v}$, Mallinckrodt) before the cells were added. Control and DMSO-treated cultures attained final densities of $1.4 \times 10^{8}$ cells $/ \mathrm{ml}$ and $9.5 \times 10^{5}$ cells $/ \mathrm{ml}$, respectively, and had viabilities (determined by erythrosin B dye exclusion) greater than $90 \%$. More than $90 \%$ of the cells in the treated cultures were benzidine-positive [21] at $120 \mathrm{~h}$, in contrast to the controls which contained less than $1 \%$ benzidine-positive cells. Periodic assays of this cell line for mycoplasma contamination, using the uridine phosphorylase assay of Levine [22] and PPLO broth cultures, were negative.

\section{Preparation and fractionation of chromatin}

Chromatin was prepared by a modification of the procedure of Huang \& Huang [23]. All steps were performed at $0-4^{\circ} \mathrm{C}$. Cells were homogenized in $0.5 \mathrm{M} 2$ methyl-3,4-pentanediol, $1 \mathrm{mM} \mathrm{CaCl}, 0.1 \mathrm{mM}$ piperazine- $N, N$-bis(2-ethane sulfonic acid) (PIPES), pH 6.0-6.5, with Dounce hand homogenizers. The nuclear fraction was pelleted at $400 \mathrm{~g}$ for $10 \mathrm{~min}$, washed three times with $0.25 \mathrm{M}$ sucrose, $5 \mathrm{mM} \mathrm{MgCl}_{2}, 5 \mathrm{mM} \beta$ mercaptoethanol, $10 \mathrm{mM}$ Tris (pH 7.2), and centrifuged as before. Nuclei prepared in this manner were free of cytoplasmic tags, as observed by phase contrast microscopy. The nuclei were then disrupted by resuspension in a solution containing $75 \mathrm{mM} \mathrm{NaCl}$ and 24 mM EDTA (pH 7.0). The material was pelleted at $12000 \mathrm{~g}$ for $10 \mathrm{~min}$. The sample was then washed twice with each of the following series of buffers: $50 \mathrm{mM}$ Tris (pH 8.0), $10 \mathrm{mM}$ Tris (pH 8.0), then $5 \mathrm{mM}$ Tris (pH 8.0). Finally, the pellet was washed once with $1 \mathrm{mM}$ Tris (pH 8.0) and centrifuged at $31000 \mathrm{~g}$ for $15 \mathrm{~min}$. The resultant viscous purified chromatin had protein/ RNA/DNA ratios of 2.60:0.16:1.00 and contained 70$85 \%$ of the total cellular DNA.

Chromatin was fractionated by a modification of the procedure of Gottesfeld et al. [16] after an overnight dialysis against $1000 \mathrm{ml}$ of $25 \mathrm{mM}$ sodium acetate $(\mathrm{pH}$ $6.6)$ at $4^{\circ} \mathrm{C}$. The chromatin was resuspended with a Dounce homogenizer ( $5-10$ strokes with a tight pestle) and adjusted to $A_{260}^{1 \mathrm{~cm}}=10$. DNase II (Worthington), dissolved in $25 \mathrm{mM}$ sodium acetate, was added to a concentration of $100 \mathrm{U} / \mathrm{ml}$, and the suspension was stirred for $5 \mathrm{~min}$ at $23^{\circ} \mathrm{C}$. The incubation was stopped by adjusting the $\mathrm{pH}$ to 7.5 , chilling on ice, and centrifuging 
at $27500 \mathrm{~g}$ for $20 \mathrm{~min}$ at $4^{\circ} \mathrm{C}$. The pellet $\left(P_{1}\right)$ which contained $86-88 \%$ of the DNA was frozen immediately at $-20^{\circ} \mathrm{C}$. A $0.2 \mathrm{M} \mathrm{MgCl}_{2}$ solution was added dropwise to the rapidly-stirring supernatant to attain a concentration of $2 \mathrm{mM} \mathrm{MgCl}$. The stirring was continued for another $30 \mathrm{~min}$ at $4^{\circ} \mathrm{C}$, and the suspension was then centrifuged as before. The pellet $\left(\mathrm{P}_{2}, 7-9 \%\right.$ of the DNA) was frozen immediately, and the supernatant $\left(S_{2}\right)$, which contained only $3-5 \%$ of the DNA, was centrifuged at $234000 \mathrm{~g}$ for $24 \mathrm{~h}$ at $4^{\circ} \mathrm{C}$ in a Beckman SW 50.1 rotor.

\section{Estimation of the transcriptional activity of chromatin fractions}

Control and treated cells were pulsed separately for 10 min at $37^{\circ} \mathrm{C}$ with $\left[{ }^{14} \mathrm{C}\right]$ uridine $(447 \mathrm{mCi} / \mathrm{mmole}$, New England Nuclear) at $5 \mu \mathrm{Ci} / \mathrm{ml}$ and $\left[{ }^{3} \mathrm{H}\right]$ uridine $(20 \mathrm{Ci} /$ mmole, Nuclear Dynamics) at $10 \mu \mathrm{Ci} / \mathrm{ml}$, respectively. The pulse was terminated by the addition of ice-cold $0.15 \mathrm{M} \mathrm{NaCl}$ solution to each culture and centrifugation at $400 \mathrm{~g}$ for $10 \mathrm{~min}$ at $4^{\circ} \mathrm{C}$. The cell pellets were then washed separately three times with cold $0.15 \mathrm{M}$ $\mathrm{NaCl}$ solution, mixed together, and the various chromatin fractions prepared as described above. Unfractionated chromatin (UC) and chromatin from $\mathbf{P}_{1}, \mathbf{P}_{2}$ and $S_{2}$ were precipitated with ice-cold $10 \%$ trichloroacetic acid (TCA), washed once with $10 \%$ TCA, hydrolysed by heating at $80^{\circ} \mathrm{C}$ for $20 \mathrm{~min}$, and recentrifuged. Aliquots of this final supernatant were taken for DNA assays and radioactivity determinations. DNA was determined using the diphenylamine procedure of Burton [24] with calf thymus DNA as standard. Samples were counted in $10 \mathrm{ml}$ of Scintisol (Isolab): $8 \%$ 2,5-diphenyl-oxazole (PPO)-toluene $(1: 6)$ in a Packard Tri-Carb liquid scintillation spectrometer. Each fraction was corrected for quench and ${ }^{14} \mathrm{C}$ to ${ }^{3} \mathrm{H}$ cross-over by comparison with quenched standards, using computer programs developed by P. Schwartz and J. Drach at the University of Michigan Dental Research Institute.

\section{Extraction and electrophoresis of chromatin-associated proteins}

Histones were extracted from chromatin fractions of control and treated cells with ice-cold $0.25 \mathrm{~N} \mathrm{HCl}$ for $2 \mathrm{~h}$ at $4^{\circ} \mathrm{C}$. De-histonized chromatin was pelleted at $31000 \mathrm{~g}$ for $30 \mathrm{~min}$ at $4^{\circ} \mathrm{C}$. The volumes of cach supernatant were measured, and aliquots were taken to determine the total amount of histone using the Lowry method [25] with bovine serum albumin as standard. The remainder of the supernatant was concentrated on dry sucrose, then dialysed against a solution of 0.9 $\mathrm{N}$ acetic acid and $15 \%$ sucrose overnight at $4^{\circ} \mathrm{C}$. Histones were electrophoresed on $15 \%$ polyacrylamide gels containing $2.5 \mathrm{M}$ urea and $0.9 \mathrm{~N}$ acetic acid as described by Panyim \& Chalkley [26].

Lipids were removed from the histone-extracted pellets by washing once with each of the following solvents: $80 \%$ ethanol, $0.1 \mathrm{~N} \mathrm{HCl} ; 50 \%$ chloroform, $50 \%$ methanol; $75 \%$ ethanol, $25 \%$ ether. The samples were centrifuged between each wash at $31000 \mathrm{~g}$ for $20 \mathrm{~min}$ at $4^{\circ} \mathrm{C}$. After lipid extraction, the non-histone chromatin proteins (NHCP) of each fraction were extracted from the pellets (after dispersion with a Tekmar Tissumizer) with a solution containing $1 \%$ sodium dodecyl sulfate (SDS), $4 \mathrm{M}$ urea, $10 \mathrm{mM} \mathrm{NaH}_{2} \mathrm{PO}_{4}$ (pH 6.9), and $5 \mathrm{mM}$ $\beta$-mercaptoethanol by heating to $100^{\circ} \mathrm{C}$ for $5-10 \mathrm{~min}$ and then shaking for $3 \mathrm{~h}$ at room temperature. The DNA in each fraction was pelleted at $198000 \mathrm{~g}$ for $24 \mathrm{~h}$ at $15^{\circ} \mathrm{C}$. The volume of each supernatant was measured, and aliquots were taken to determine the total amount of NHCP. Greater than $85 \%$ of the chromatinassociated proteins of fractions $\mathrm{UC}$ and $\mathrm{P}_{1}$ and $>95 \%$ of those of $P_{2}$ and $S_{2}$ were extracted by this procedure. The remainder of each sample was concentrated on dry sucrose at room temperature, then dialysed against $25 \mathrm{mM}$ Tris ( $\mathrm{pH} \mathrm{8.3),0.19} \mathrm{M}$ glycine, $0.1 \%$ SDS overnight at $4^{\circ} \mathrm{C}$. The NHCP were electrophoresed on discontinuous SDS-polyacrylamide gels as described by Laemmli [27].

\section{Dual radioactive isotope-labeling of chromatin-associated proteins}

Control cells were labeled with a $\left[{ }^{14} \mathrm{C}\right]$ amino acid mixture (New England Nuclear) at $3.6 \mu \mathrm{Ci} / \mathrm{ml}$, and the treated cells were exposed to $8 \mu \mathrm{Ci} / \mathrm{ml}$ of a $\left[{ }^{3} \mathrm{H}\right]$ amino acid mixture. Both sets of cultures were incubated for $2 \mathrm{~h}$ at $37^{\circ} \mathrm{C}$. The incubation was terminated by chilling on ice and centrifuging at $400 \mathrm{~g}$ for $10 \mathrm{~min}$ at $4^{\circ} \mathrm{C}$. The cells were washed separately three times with $200 \mathrm{ml}$ of ice-cold balanced salt solution. Finally, the cells were resuspended in $0.15 \mathrm{M} \mathrm{NaCl}$, pooled, and centrifuged as before.

Chromatin was prepared in the presence of sodium bisulfite and fractionated as described above. In this case the total $S_{2}$ supernatant was lyophilized prior to extraction. Histones and NHCP, extracted from the various chromatin fractions, were electrophoresed on Panyim-Chalkley and Laemmli gels, respectively. The gels were fractionated into $1 \mathrm{~mm}$ slices with a Mickle gel slicer. Each slice was allowed to swell for $48 \mathrm{~h}$ at $37^{\circ} \mathrm{C}$ in a counting vial containing $15.0 \mathrm{ml}$ of a $6 \%$ Protosol (New England Nuclear), $8 \%$ PPO, toluene cocktail. The gel slices were counted and corrected for quench and cross-over as described above. The molecular weights of the NHCP were estimated by comparison with the following standard proteins run on companion gels: $\beta$-galactosidase $(130000 \mathrm{D})$, bovine serum albumin $(68000)$, ovalbumin $(43000)$, calf thymus $\mathrm{Hl}$ histone $(23000)$.

\section{Determination of possible artifacts}

\section{due to protease activity}

Experiments were performed to determine the effects of protease inhibitors on the electrophoretic profiles of histones and NHCP. In one experiment, $1 \mathrm{mM}$ phenylmethane sulfonyl fluoride (PMSF) in $5 \%$ propanol was added to all buffers used in the preparation of chromatin. In the second, sodium bisulfite was added to the $0.25 \mathrm{M}$ sucrose and the $\mathrm{NaCl}$-EDTA solutions at a $50 \mathrm{mM}$ concentration. The $50 \mathrm{mM}$ Tris buffer was adjusted to $5 \mathrm{mM}$ sodium bisulfite. All other buffers were not altered, in order to avoid changes in the ionic strength.

The possibility of contaminating proteolytic activity 
Table 1. Specific activities of rapidlylabeled nuclear RNA in chromatin fractions from control and $1.2 \%$ DMSO-treated T3Cl-2 cells

Radioactive labeling of the RNA, isolation of chromatin fractions and determination of radioactivity and DNA in each fraction are described in Methods. $S_{z}$ pel and $S_{2}$ sup refer to the pellet and supernatant which resulted after the chromatin in the entire $S_{2}$ fraction was centrifuged at $234000 \mathrm{~g}$ for $24 \mathrm{~h}$ at $4^{\circ} \mathrm{C}$. Rel. spec. act. are dpm/ $/ \mathrm{g}$ DNA values normalized with respect to UC

\begin{tabular}{|c|c|c|c|c|}
\hline \multirow[b]{2}{*}{ Fraction } & \multicolumn{2}{|c|}{$\begin{array}{l}\text { Spec. act. } \\
(\text { dpm/ } / \mu \mathrm{g} \text { DNA) }\end{array}$} & \multicolumn{2}{|c|}{ Rel. spec. act. } \\
\hline & Control & Treated & Control & Treated \\
\hline UC & 433 & 120 & 1.00 & 1.00 \\
\hline$P_{1}$ & 62 & 32 & 0.14 & 0.27 \\
\hline $\mathrm{P}_{2}$ & 128 & 38 & 0.29 & 0.32 \\
\hline$S_{2}^{2}$ pel & 830 & 218 & 1.91 & 1.82 \\
\hline$S_{2}$ sup & 483 & 133 & 1.11 & 1.11 \\
\hline
\end{tabular}

of the commercial DNase II enzyme preparation was explored in two ways. In the first, the ability of the DNase preparation to degrade chromatin-bound histone Hl was examined. Chromatin was prepared from $\mathrm{T} 3-\mathrm{Cl}-2$ cells grown in the presence of $\left[{ }^{3} \mathrm{H}\right]$ amino acids at a concentration of $0.1 \mu \mathrm{Ci} / \mathrm{ml}$. Aliquots of the chromatin were incubated at $23^{\circ} \mathrm{C}$ with active DNase II or with enzyme previously inactivated at $90^{\circ} \mathrm{C}$ for 15 min. The concentrations of chromatin and DNase II and the incubation conditions were identical to those in the fractionation protocol. The incubations were stopped at various time points by the addition of equal volumes of ice-cold $0.5 \mathrm{~N} \mathrm{HCl}$. Histones were extracted from each active and inactive enzyme sample and compared on SDS polyacrylamide gels as described by Weber \& Osborn [28]. The gels were sliced and counted as described above.

In the second approach to this problem, active DNase II was incubated for various periods of time with $\left[{ }^{3} \mathrm{H}\right] \mathrm{L}$-amino acid-labeled Burkitt lymphoma cell chromatin at $37^{\circ} \mathrm{C}$. Proteolytic activity was followed by the release of acid soluble radioactivity as described by Weisenthal \& Ruddon [29].

\section{RESULTS}

\section{Transcriptional activities of chromatin fractions}

The transcriptional activities of the various chromatin fractions were estimated by incubating control and treated cells for $10 \mathrm{~min}$ with $\left[{ }^{14} \mathrm{C}\right]$ and $\left[{ }^{3} \mathrm{H}\right]$ uridine, respectively (ta- ble 1). A short pulse was used in order to label high molecular weight nuclear RNA, which presumably contains precursor mRNA molecules. The $S_{2}$ pel fraction in both control and treated groups exhibited the highest specific activity. These fractions were nearly twice as active when compared with the UC samples. In contrast, fractions $P_{1}$ and $P_{2}$ of control and treated groups had specific activities $0.1-0.3$ that of UC. Although the $S_{2}$ fraction $\left(S_{2}\right.$ pel $+S_{2}$ sup) represented only $3-5 \%$ of the total chromatin DNA from control and treated cells, it contained approx. $50 \%$ of the total radioactivity (data not shown).

\section{Protein composition of chromatin fractions}

The content of histone and NHCP in the various chromatin fractions is shown in table 2 . The ratio of histone to DNA was constant in all fractions and was not significantly affected by DMSO treatment. In contrast, the ratio of NHCP to DNA was con-

\section{Table 2. Protein to DNA ratios of chro- matin fractions from control and $1.2 \%$ DMSO-treated T3-Cl-2 cells}

Histone quantity was taken as the total amount of protein extracted from the chromatin fractions by $0.25 \mathrm{~N}$ $\mathrm{HCl}$. NHCP was determined as the amount of protein removed by $1 \% \mathrm{SDS}, 4 \mathrm{M}$ urea, $10 \mathrm{mM} \mathrm{NaH}_{2} \mathrm{PO}_{1}(\mathrm{pH}$ 6.9) plus residual protein bound to DNA and not extracted by this process. The amount of residual protein for UC and $P_{1}$ was $<15 \%$ of the total protein removed, while that of the $P_{2}$ and $S_{2}$ fractions was $<5 \%$. Ratios are expressed as a mean \pm S.E.M., and are based upon 4-6 separate chromatin preparations

\begin{tabular}{llllll}
\hline \multirow{2}{*}{$\begin{array}{l}\text { Frac- } \\
\text { tion }\end{array}$} & \multicolumn{2}{l}{ Control } & Treated & & \multicolumn{2}{l}{ NHCP/DNA } \\
\cline { 5 - 6 } \cline { 5 - 6 } & Control & Treated \\
\hline$U C$ & $1.36 \pm 0.21$ & $1.35 \pm 0.15$ & & $2.55 \pm 0.69$ & $1.54 \pm 0.43$ \\
$P_{1}$ & $1.38 \pm 0.20$ & $1.17 \pm 0.04$ & & $2.08 \pm 0.70$ & $0.91 \pm 0.14$ \\
$P_{2}$ & $1.37 \pm 0.23$ & $1.55 \pm 0.29$ & & $0.40 \pm 0.12$ & $0.49 \pm 0.09$ \\
$S_{2}$ & $1.28 \pm 0.23$ & $1.22 \pm 0.19$ & & $1.74 \pm 0.21$ & $1.88 \pm 0.33$ \\
\hline
\end{tabular}




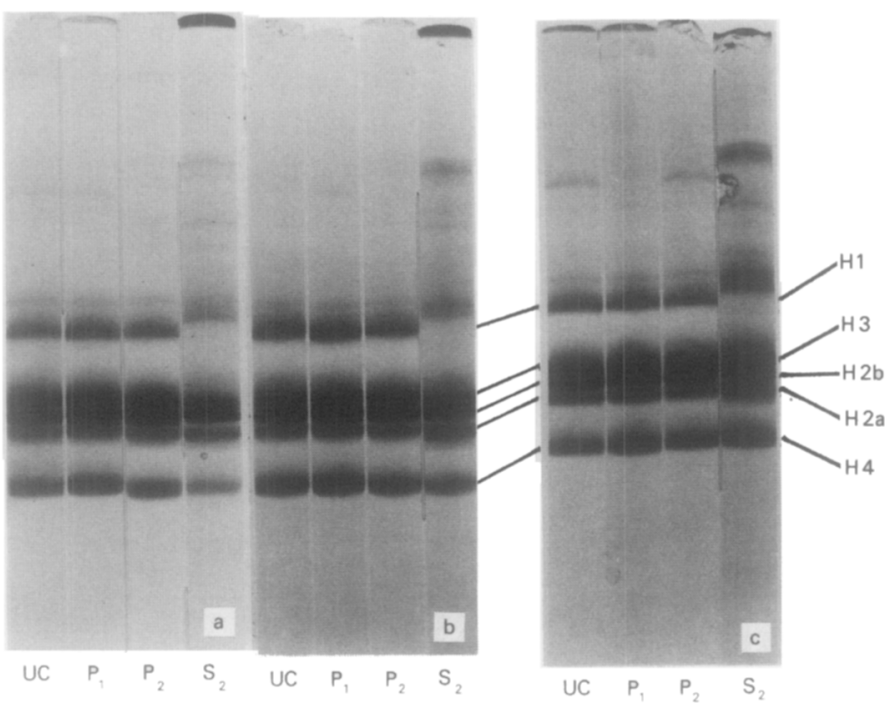

Fig. 1. Gel banding patterns of histones isolated from chromatin fractions of control and $1.2 \%$ DMSOtreated cells grown in culture for $120 \mathrm{~h}$.

Histones from: (a) control cell chromatin fractions; $(b)$ treated cell chromatin fractions; $(c)$ treated cell chromatin fractions which were isolated in the presence of sodium bisulfite. Electrophoresis was conducted on gels measuring $0.6 \times 7.5$ $\mathrm{cm}$ as described in Methods. Direction of migration is top to bottom, and the major histones are indicated at the right of gel set $(c)$. Fifteen $\mu \mathrm{g}$ of protein was layered for $\mathrm{UC}, \mathrm{P}_{1}$ and $P_{2} ; 25-30 \mu \mathrm{g}$ of protein for $S_{2}$. Gels were stained for $4 \mathrm{~h}$ with $0.25 \%$ Coomassie Brilliant Blue, $45 \%$ methanol, $10 \%$ acetic acid and destained in $7.5 \%$ acetic acid, $5 \%$ methanol at $60^{\circ} \mathrm{C}$. sistently lower in chromatin fraction $\mathrm{P}_{2}$ as compared with other fractions.

There were no differences in the polyacrylamide gel banding patterns of histones from corresponding fractions of control and treated cells (fig. 1 $a, b$ ). Furthermore, within each control and treated group, the histones from UC, $P_{1}$, and $P_{2}$ were identical. The histone patterns of control and treated $S_{2}$, although identical with each other, were markedly different from those of the other fractions. The most striking difference was the absence of the usual amount of $\mathrm{H} 1$ histone. In the $S_{2}$ fractions there were two bands with mobilities slightly slower than $\mathrm{H} 1$ histone. One of the slower migrating bands was also visible in the UC, $P_{1}$, and $P_{2}$ fractions. A number of higher molecular weight polypeptides were also evident in both $\mathrm{S}_{\mathbf{2}}$ fractions, including material which remained at the top of the gels.

NHCP isolated from chromatin fractions of control and treated cells were examined by electrophoresis on discontinuous SDSpolyacrylamide gels. Differentiation induced by DMSO did not result in observ- able differences in the banding patterns of NHCP (fig. $2 a, b$ ). In both control and treated groups, the patterns from UC and $P_{1}$ were nearly identical. This was not unexpected since $P_{1}$ contained the majority of the DNA. The $\mathrm{P}_{2}$ fraction differed from UC and $P_{1}$ in that there were fewer low molecular weight bands on the gels. NHCP of transcriptionally active chromatin $\left(\mathbf{S}_{2}\right)$ from control and treated groups were similar to each other, containing prominent bands at 68000,40000 and $23000-30000 \mathrm{D}$.

\section{$\left[{ }^{3} \mathrm{H}\right]$ and $\left[{ }^{14} \mathrm{C}\right]$ amino acid-labeled chromatin-associated proteins}

The dual isotope technique was employed in order to provide a more sensitive analysis of alterations in histones and NHCP from chromatin fractions prepared from control and $1.2 \%$ DMSO-treated cells. The UC, $\mathrm{P}_{1}$, and $\mathrm{P}_{2}$ histone profiles were nearly identical (fig. $3 a-c$ ). All three fractions exhibited two major radioactive bands in the $\mathrm{H} 1$ region. In the treated sample, the band in the usual $\mathrm{H} 1$ position had a higher specific activity than that of the slower-migrating second band. 


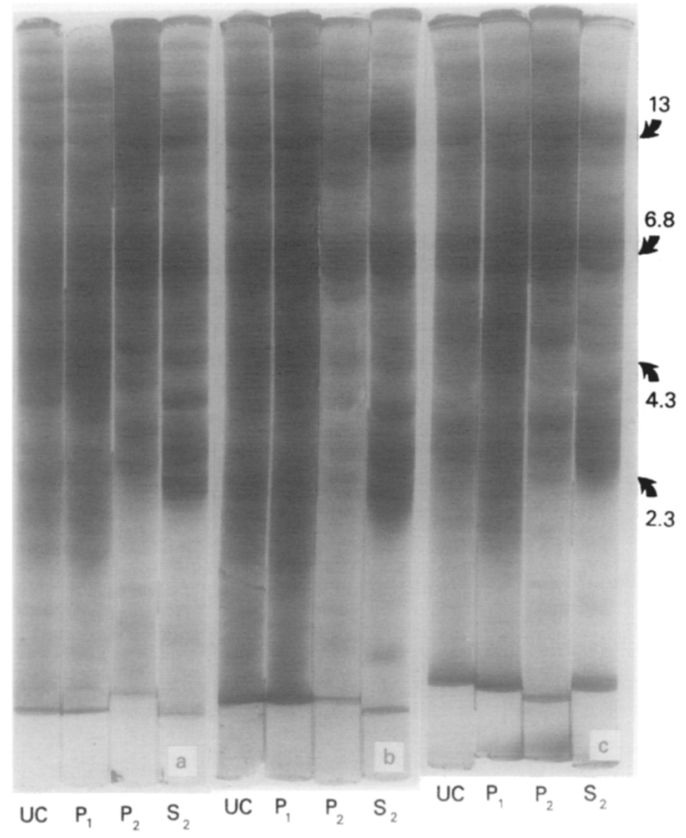

Fig. 2. Gel banding patterns of NHCP isolated from chromatin fractions of control and $1.2 \%$ DMSOtreated cells grown in culture for $120 \mathrm{~h}$. NHCP from (a) control cell chromatin fractions; $(b)$ treated cell chromatin fractions; $(c)$ treated cell chromatin fractions which were isolated in the presence of $1 \mathrm{mM}$ PMSF. Electrophoresis was performed on gels measuring $0.6 \times 9 \mathrm{~cm}$ as described in the Methods. Direction of migration is top to bottom, and the approximate mol. wt indicated on the right of gel set $(c)$ are multiplied by a factor of $1 \times 10^{4} .100-300 \mu \mathrm{g}$ of protein was layered; all gels within each set contained the same amount of protein. The gels were stained with Coomassie Brilliant Blue, as described in fig. 1.

This relationship was reversed in the control cell sample. Histones $\mathrm{H} 3, \mathrm{H} 2 \mathrm{~b}$, and $\mathrm{H} 2 \mathrm{a}$ were not well resolved and migrated as a single broad band. The $S_{2}$ histone patterns (fig. $3 d$ ) from control and treated cells, although similar to each other, were markedly different from the profiles of the other fractions. The radioactivity contained in the histone bands was lower than that of two slower migrating polypeptides (fractions 1823 and fractions 36-39). These two peaks corresponded in molecular weight to stained bands described earlier for the $S_{2}$ histones (fig. 1). In addition, approx. $25 \%$ of the radioactivity in the $\mathrm{S}_{2}$ fraction of both groups was found in the first gel slice.

The profiles of radioactively labeled NHCP isolated from the four chromatin fractions are shown in fig. 4. For the most part, the NHCP from UC and $\mathrm{P}_{1}$ resembled each other (fig. $4 a, b$ ). There were prominent peaks at 50000,63000 , and $>104000 \mathrm{D}$ in both chromatin fractions from control and treatcd cells. The most striking difference was the increased incorporation of radiolabel into the $50000 \mathrm{D}$ band of the $\mathrm{UC}$ and $P_{1}$ chromatin fractions from treated cells. The $\mathrm{P}_{2}$ fraction also contained several distinct radiolabeled polypeptides (fig. $4 c$ ), and there were some differences between control and treated samples. The prominent $50000 \mathrm{D}$ band observed in the UC and $\mathrm{P}_{1}$ samples from treated cells was not present in $P_{2}$. The NHCP in $S_{2}$ from control and treated cultures were similar to each other but different from UC, $P_{1}$, and $P_{2} . S_{2}$ contained a number of radioactive bands in the $20000-30000 \mathrm{D}$ range. There was increased labeling of a $23000 \mathrm{D}$ polypeptide in the treated sample.

\section{Lack of significant proteolytic activity in the DNase II preparation and Friend cell chromatin}

Because the absence of the $\mathrm{H} 1$ histone in $\mathrm{S}_{2}$ as well as the observed differences in NHCP might be explained by proteolytic degradation $[29,30]$, the DNase II preparation and unfractionated Friend cell chromatin were examined for protease activity. Proteolytic contamination of the commercial DNase II, which could possibly be carried along into the $S_{2}$ supernatant, was checked by two methods. The DNase II enzyme was incubated with UC from T3-Cl-2 cells for $5 \mathrm{~min}$ and $6 \mathrm{~h}$ at $23^{\circ} \mathrm{C}$ (fig. 5). The amount and distribution of labeled histone 


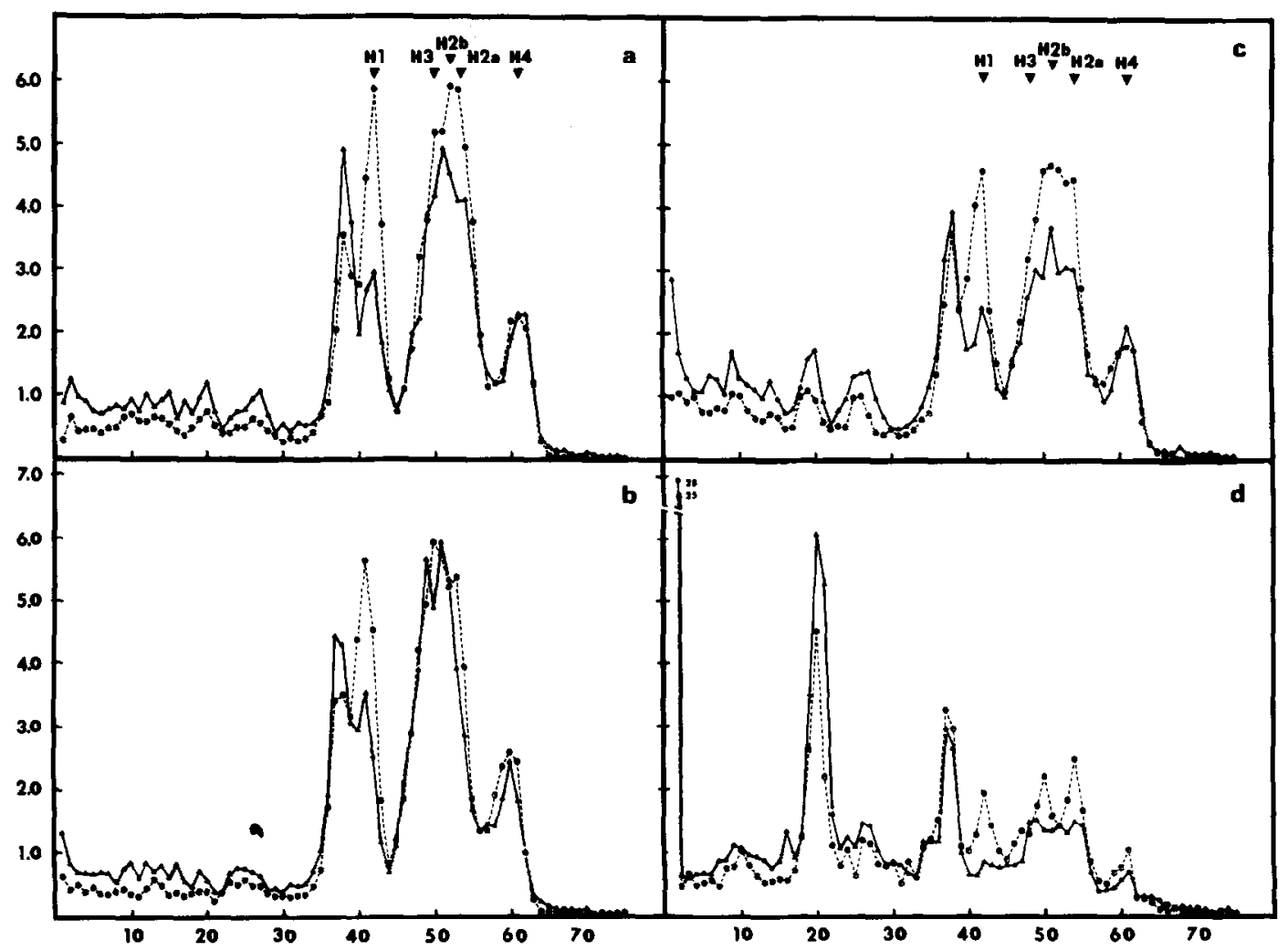

Fig. 3. Abscissa: gel slice no.; ordinate: $\%$ of total dpm on each gel.

Electrophoretic profiles of radiolabeled histones isolated from chromatin fractions of control and $1.2 \%$ DMSO-treated cells grown in culture for $120 \mathrm{~h}$. Histones extracted from (a) UC; (b) $\mathrm{P}_{1} ;(c) \mathrm{P}_{2} ;(d) \mathrm{S}_{2}$ frac-

tions. Control cell samples $(\boldsymbol{A}-\boldsymbol{A})$; treated cell samples (O-O). Procedures for double-isotope analysis of the radiolabeled histones are described in Methods. The total ${ }^{3} \mathrm{H}+{ }^{14} \mathrm{C}$ radioactivity layered on each gel was $20000 \mathrm{cpm}$. Major histones are indicated at the top of $(a)$ and $(c)$.

isolated from $5 \mathrm{~min}$ and $6 \mathrm{~h}$ incubations, with or without active DNase II, were essentially identical. Since $\mathrm{H} 1$ is the histone most susceptible to proteolytic attack in chromatin $[29,30]$, the lack of significant degradation of $\mathrm{H} 1$ histone at either $5 \mathrm{~min}$ or $6 \mathrm{~h}$ of incubation indicates that the DNase II preparation as well as purified Friend cell chromatin were relatively free of significant protease activity. The DNase II preparation was also checked for protease activity by the release of acid-soluble counts from Burkitt lymphoma cell chromatin proteins after various periods of incubation at $37^{\circ} \mathrm{C}$. Release of acid-soluble counts was $0.34 \%$ af-

ter $5 \mathrm{~min}$ and $7.6 \%$ after $6 \mathrm{~h}$ of incubation. Finally, the effect of protease inhibitors on the gel banding patterns of chromatin proteins was examined. Sodium bisulfite did not alter the amount of $\mathrm{H} 1$ histone in treated $\mathrm{S}_{2}$ chromatin (fig. $1 c$ ), nor did isolation of treated cell chromatin in the presence of the serine protease inhibitor PMSF (1 mM) significantly alter the NHCP banding patterns obtained (fig. $2 c$ ).

\section{DISCUSSION}

The specific activities of the nascent RNA in the $\mathrm{S}_{2}$ chromatin fractions from both con- 


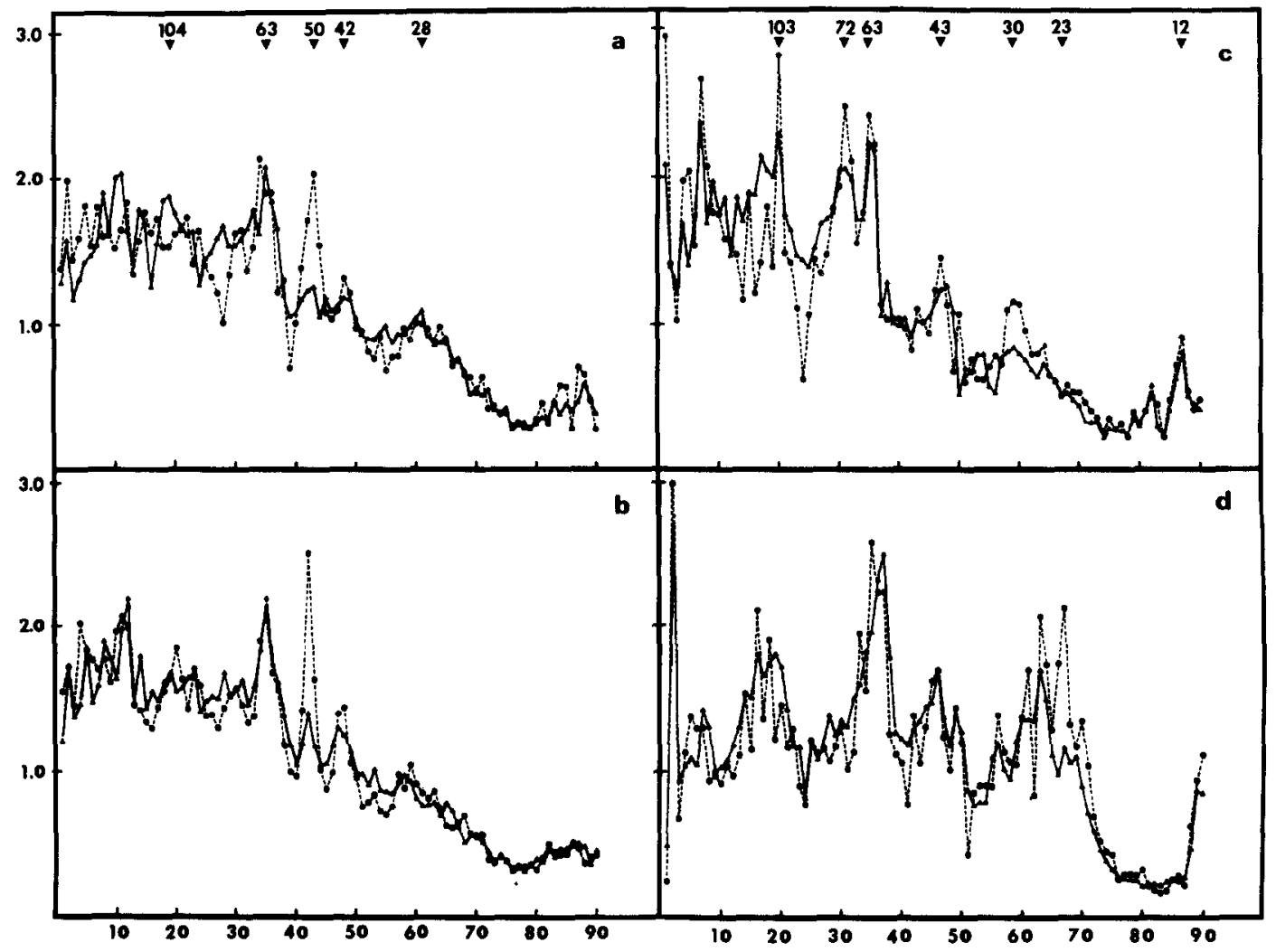

Fig. 4. Abscissa: gel slice no.; ordinate: \% of total dpm on each gel.

Electrophoretic profiles of radiolabeled NHCP isolated from chromatin fractions of control and $1.2 \%$ DMSO-treated cells grown in culture for $120 \mathrm{~h}$. NHCP extracted from (a) UC; (b) $P_{1} ;(c) P_{2} ;(d) S_{2}$ fractions.

Control cell samples $(\boldsymbol{\Delta} \mathbf{\Delta})$; treated cell samples (O-.-O). Procedures for double-isotope analysis of the radiolabeled NHCP are described in the Methods. Total ${ }^{3} \mathrm{H}+{ }^{14} \mathrm{C}$ radioactivity layered on each gel was $100000 \mathrm{cpm}$. Molecular weight values indicated at the top of $(a)$ and $(c)$ are multiplied by a factor $1 \times 10^{3}$.

trol and treated Friend cells suggest that these fractions are the most transcriptionally active (table 1). On the other hand, the $P_{1}$ and $P_{2}$ fractions appear to represent transcriptionally inactive chromatin. These results support those of Gottesfeld et al. [16], who have shown that the $S_{2}$ fraction from rat liver chromatin not only has the highest in vitro template activity but is also enriched for DNA sequences coding for cellular RNA. The $S_{2}$ fraction of Friend cell chromatin which comprises $5 \%$ of the DNA contains about $50 \%$ of the total $\left[{ }^{3} \mathrm{H}\right]$ uridine counts incorporated into nuclear RNA dur- ing the $10 \mathrm{~min}$ pulse. This suggests that the $\mathrm{S}_{2}$ fraction prepared by the DNase II method is enriched for actively transcribed DNA sequences; it does not contain all the actively transcribed regions.

Analysis of the protein component of chromatin from control and DMSO-treated T3-Cl-2 cells indicates that nearly equivalent amounts of histones are present in actively and inactively transcribed fractions (table 2). Similarly, with the exception of $P_{2}$, there are no significant differences in NHCP/DNA ratios of the various chromatin fractions. These protein to DNA ratios 


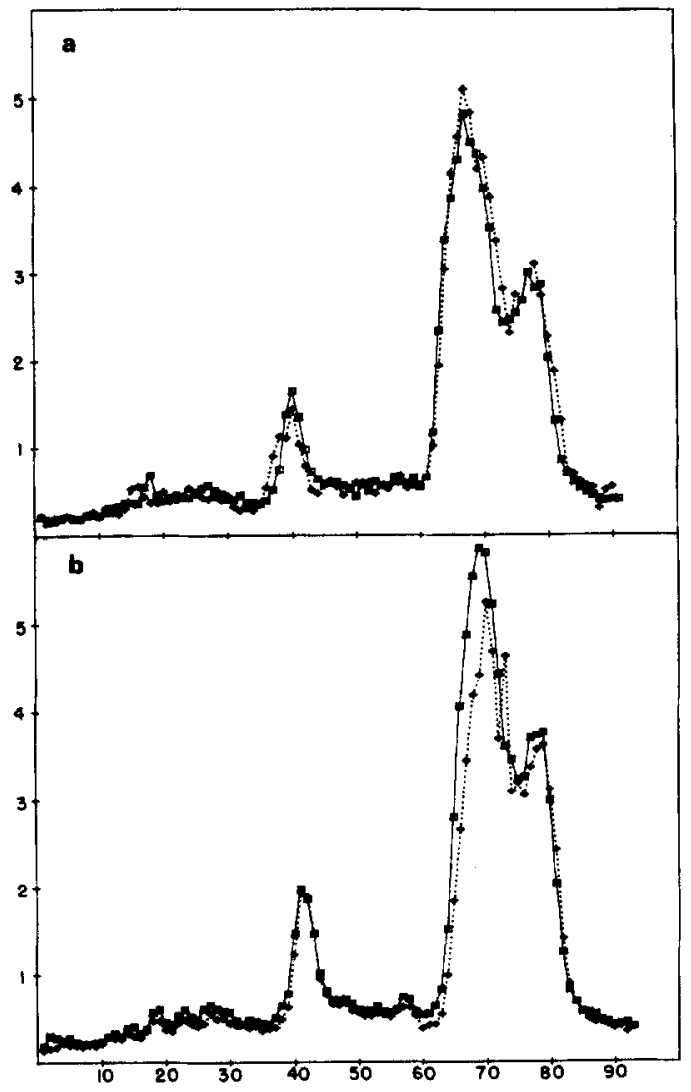

Fig. 5. Abscissa: gel slice no.; ordinate: \% of total dpm on each gel.

Absence of proteolytic activity in the DNase II enzyme preparation. Unfractionated chromatin from T3$\mathrm{Cl}-2$ cells was incubated with active (-.-) or heatinactivated ( $[0-0)$ DNase II enzyme for: $(a) 6 \mathrm{~h}$, or (b) $5 \mathrm{~min}$. Incubation conditions, extraction and electrophoresis (on $0.8 \times 10 \mathrm{~cm}$ gels) of histones are described in the Methods. Total radioactivity layered on each gel was between $20000-30000 \mathrm{cpm}$. 80-89\% and $94-98 \%$ of the total radioactivity layered was recovered in the gel slices for the $6 \mathrm{~h}$ and $5 \mathrm{~min}$ incubations, respectively.

are not significantly affected by the presence of contaminating DNase II since the chromatin in all fractions is pelleted during the fractionation procedure. Furthermore, bands corresponding to the two major bands seen on SDS gels of an SDS-treated DNase II preparation do not appear on the SDS gels of NHCP preparations from the chromatin fractions (data not shown). Basic non-histone proteins (acid-extractable) do not appear to contribute significantly to the histone/DNA ratios of unfractionated chromatin, $P_{1}$ and $P_{2}$, since these samples contain very little material which does not migrate as one of the five major histone bands on acetic acid-urea polyacrylamide gels (fig. $1 a, b$ ). The histone fraction from $\mathrm{S}_{2}$, however, does appear to contain acidextractable non-histone proteins. The gels from $S_{2}$ histone fractions contain distinct protein bands with mobilities less than $\mathrm{H} 1$ histone, plus material that remains at the top of the gels (fig. $1 a, b$ ). It is unlikely that any of these other polypeptide species represent DNase II enzyme since: (i) the chromatin in each fraction was pelleted from solution at least once; and (ii) they correspond to material which is radioactively labeled in vivo (figs 1,3 ). Some of these bands may represent the high mobility group (HMG) non-histone proteins which frequently contaminate acid extracts of chromatin [31]. If this is the case, the NHCP/DNA ratios of the active $S_{2}$ fractions would actually be higher and the histone/DNA ratios lower than that indicated in table 2.

The gel banding patterns of the $S_{2}$ histones also indicate a lack of $\mathrm{H} 1$ histone in both control and treated $\mathbf{S}_{\mathbf{2}}$ fractions (fig. $1 a, b)$. This deficiency is probably not due to proteolytic degradation since: $(i)$ at the ionic strength ( $25 \mathrm{mM}$ sodium acetate) and $\mathrm{pH}$ (6.6) of the buffer used during the isolation of $S_{2}$, chromatin-associated protease activity is reported to be minimal [30, 32]; (ii) the protease activities of T3-Cl-2 chromatin and the DNase II enzyme preparation are negligible (fig. 5); and (iii) the use of 50 $\mathrm{mM}$ sodium bisulfite does not prevent the absence of $\mathrm{H} 1$ histone (fig. 1c). The effectiveness of sodium bisulfite as a histone protease inhibitor has recently been called 
into question when used in the presence of high salt-urea solutions (i.e. $2 \mathrm{M} \mathrm{NaCl}, 5 \mathrm{M}$ urea, pH 8.0) [32]; however, bisulfite has been shown to be an effective protease inhibitor at the $\mathrm{pH}$ and ionic strengths utilized in the present study $[30,33]$. Finally, the lack of $\mathrm{H} 1$ histone has also been observed in active chromatin isolated by other techniques [14, 17]. This finding is consistent with experiments implicating $\mathrm{H} 1$ histone in the restriction of template activity [34] and condensation of chromatin [35].

Double isotope labeling procedures were employed in order to provide a more sensitive means of detecting alterations in chromatin proteins after DMSO stimulation. Incorporation of radioactive amino acids into the histones of both control and treated groups (fig. 3) indicates that histone synthesis is still occurring although the cultures are apparently in a stationary growth phase (data not shown). Since the bulk of histone synthesis is coupled to DNA synthesis, this incorporation may be due to a small population of dividing cells. The higher specific activity of the treated cell histones may reflect a slightly larger percentage of dividing cells in the treated cultures. The apparently reduced radioactivity of the major histones in the $S_{2}$ fraction is most likely due to the higher percentage of the total radioactivity found in gel slice 1 and slices 18-23 (fig. 3d). The identity of the labeled polypeptides in the $S_{2}$ histone fraction represented by slices $1,18-23$, and 3639 (fig. $3 d$ ) is not certain. Some of these may be HMG proteins as noted above. In addition, modified forms of histones, for example, dimeric forms of histone $\mathrm{H3}$ [36] and phosphorylated forms of $\mathrm{Hl}$ histone $[37,38]$, have been shown to have a decreased electrophoretic mobility. It is also noteworthy that a low level of radioactivity is present in the usual $\mathrm{Hl}$ histone position of the electropherogram of the $S_{2}$ histone fractions (fig. $3 d$ ). Thus, although $\mathrm{H} 1$ histone is not detectable by Coomassie blue staining (fig. 1), a small amount does appear to be present.

NHCP bands resolved by SDS-polyacrylamide gel electrophoresis have not been definitively identified, but they probably represent a mixture of structural proteins, nuclear enzymes, and gene regulatory proteins. The latter subset of proteins could contain those NHCP involved in the transcription of globin mRNA in DMSO-stimulated cells. While there are no remarkable differences between banding patterns of the NHCP from the chromatin of treated and control cells detected by staining with Coomassie blue (fig. 2), several differences are observed between the profiles of radioactively labeled NHCP from control and treated chromatin fractions (fig. 4). The most prominent alterations are the increases in radioactivity of a $50000 \mathrm{D}$ polypeptide in the treated cell UC and $\mathrm{P}_{1}$ fractions (fig. $4 a$, $b$ ) and a $23000 \mathrm{D}$ polypeptide in the treated $\mathrm{S}_{2}$ fraction (fig. $4 d$ ). It should be noted that Peterson \& McConkey [39] also observed a significant increase in a $25000 \mathrm{D}$ non-histone protein isolated from DMSO-stimulated erythroleukemia cells and identified by two-dimensional gel electrophoresis.

The significance of the elevated incorporation of labeled amino acids into the 50000 and $23000 \mathrm{D}$ polypeptides is not currently evident. Although it is attractive to speculate that these polypeptides are involved in the apparently altered gene transcription of the DMSO-treated Friend cell, there is currently little evidence to support this. The possibility that the observed alterations of NHCP are related to a small difference in the proliferative state of the treated and control cultures, which the differences in histone synthesis seem to support, has not 
been ruled out. The observed differences in labeled NHCP banding patterns are not likely to be the result of differential proteolytic degradation since the treated and control cells were pooled prior to chromatin isolation. Moreover, $1 \mathrm{mM}$ PMSF does not appear to significantly alter the banding patterns of NHCP from treated cells (fig. 2c).

Since DMSO-stimulation of these cells also results in the accumulation of type $C$ virus particles in intra-cytoplasmic vacuoles, on cell membranes, and in the culture fluid [40], an alternative explanation for the increased incorporation of radioactivity into certain NHCP peaks is that this represents an increased synthesis of virus-specific proteins. This question has not yet been examined directly, but two factors argue against this explanation: (i) viral particles are located primarily in the cytoplasm of the cell [40]; and (ii) electrophoresis of the proteins from purified Friend virus on SDS-polyacrylamide gels indicates that the predominant viral polypeptides have molecular weights of $14000,17000,19000$, 34000,93000 , and $150000 \mathrm{D}$ [41]. These proteins do not correspond to those radioactive peaks in the NHCP fractions which exhibit marked differences between control and treated samples.

A next step will be to purify sufficient amounts of the NHCP whose synthesis appears to be elevated in DMSO-treated Friend cells for further biochemical characterization. It will be of interest to determine, e.g. by chromatin reconstitution studies, whether this or other NHCP from the active chromatin fraction of treated cells can induce the in vitro synthesis of globin mRNA by chromatin which does not normally transcribe the globin message. The question whether there is a detectable shift in the globin gene from the inactive to the active gene pool, as determined by the
DNase II method, during DMSO stimulation is under investigation (manuscript in preparation).

A preliminary report of this data was presented at the annual meeting of the American Association for Cancer Research. May 4-8, 1976.

This research was supported by NIH Grant CA12765. Data were calculated with the help of the University of Michigan Medical School fund for computing.

\section{REFERENCES}

1. Friend, C, Scher, W, Holland, J G \& Sato, T, Proc natl acad sci US 68 (1971) 378.

2. Ostertag, W, Melderis, H, Steinheider, G, Kluge, N \& Dube, S, Nature new biol 239 (1972) 231.

3. Ikawa, Y \& Sugano, H, Gann 57 (1966) 641.

4. Ikawa, Y, Furusawa, M \& Sugano, H, Unifying concepts of leukemia, Bibl haemat, No. $39(\mathrm{ed} \mathrm{R} \mathrm{M}$ Dutcher \& L Chieco-Biachi) vol. 39, p. 955. Karger, Basel (1973).

5. Kabat, D, Sherton, C C, Evans, L H, Bigley, R \& Koler, R D, Cell 5 (1975) 331.

6. Ebert, P S \& Ikawa, Y, Proc soc exp biol and med 146 (1974) 601

7. Takahashi, E, Nagasawa, T, Sato, S, Matsushima, T, Sugimura, T \& Ohashi, A, Gann 65 (1974) 261.

8. Ross, J, Gielen, J, Packman, S, Ikawa, Y \& Leder, P, J mol biol 87 (1974) 697.

9. Gilmour, R S, Harrison, P R, Windass, J D, Affara, N A \& Paul, J, Cell diff 3 (1974) 9.

10. Orkin, S H, Swan, D \& Leder, P, J biol chem 250 (1975) 8753.

11. Frenster, I H, Allfrey, V G \& Mirsky, A E, Proc natl acad sci US 50 (1963) 1026.

12. Elgin, S C R \& Weintraub, H, Ann rev biochem 44 (1975) 725 .

13. Anderson, $\mathrm{K} M$, Chance, $\mathrm{H}$ \& Kadohama, N, Exp cell res 94 (1975) 176.

14. Berkowitz, E M \& Doty, P, Proc natl acad sci US 72 (1975) 4404.

15. Simpson, R T, Proc natl acad sci US 71 (1974) 2740.

16. Gottesfeld, J M, Garrard, W T, Bagi, G, Wilson, R F \& Bonner, J, Proc natl acad sci US 71 (1974) 2193.

17. Simpson, R T \& Reeck, G R, Biochemistry 12 (1973) 3853.

18. Gottesfeld, J M, Bagi, G, Berg, B \& Bonner, J, Biochemistry 15 (1976) 2472.

19. Gottesfeld, J M, Murphy, R F \& Bonner, J, Proc natl acad sci 72 (1975) 4404.

20. Billing, R J \& Bonner, J, Biochim biophys acta 281 (1972) 453.

21. Orkin, S H, Harosi, F I \& Leder, P, Proc natl acad sci US 72 (1975) 98.

22. Levine, E M, Exp cell res 74 (1972) 99.

23. Huang, R-C C \& Huang, P C, J mol biol 39 (1969) 365.

24. Burton, K, Methods in enzymol 12 (1968) 163. 
25. Lowry, O H, Rosebrough, N J, Farr, A L \& Randall, R J, J biol chem 193 (1951) 265.

26. Panyim, S \& Chalkley, R, Arch biochem and biophys 130 (1969) 337.

27. Laemmli, U K, Nature 227 (1970) 680.

28. Weber, K \& Osborn, M, J biol chem 244 (1969) 4406.

29. Weisenthal, L M \& Ruddon, R W, Cancer res 33 (1973) 2923.

30. Bartley, J \& Chalkley, R, J biol chem 245 (1970) 4286.

31. Johns, E W, Goodwin, G H, Walker, J M \& Sanders, $C$, The structure and function of chromatin, Ciba Foundation symp (ed D W Fitzsimons \& G E W Wolstenholme) p. 95. Associated Scientific Publishers, Amsterdam (1975).

32. Carter, D B \& Chae, C B, Biochemistry 15 (1976) 180.

33. Panyim, S, Jensen, R H \& Chalkley, R, Biochim biophys acta 160 (1968) 252 .
34. Georgiev, G P, Amanieva, L N \& Kozlov, J V, J mol biol 22 (1966) 365.

35. Bradbury, E M, Danby, S E, Rattle, H W E \& Giancotti, V, Eur j biochem 57 (1975) 97.

36. Johmann, D, Eckhardt, R A \& Gorovsky, M A. J cell biol 58 (1973) 119.

37. Lake, R S, Goidl, J A \& Salzman, N P, Exp cell res 73 (1972) 113.

38. Kraus, M O \& Inasi, B S, Arch biochem biophys 164 (1974) 179.

39. Peterson, J L \& McConkey, E H, J biol chem 251 (1976) 555.

40. Sato, T, Friend, C \& deHarven, E, Cancer res 31 (1971) 1402.

41. Schäfer, W, Lange, J, Fishinger, P J, Frank, H, Bolognesi, D P \& Pister, L, Virology 47 (1972) 210.

Received September 15, 1976

Accepted January 12, 1977 